\section{Superoxide Generating System}

\section{Hideharu Shintani ${ }^{\star}$}

Chuo University, School of Science, 1-13-27, Kasuga Bunkyo 112-0003 Tokyo, Japan

Keywords: Csuperoxide anion radical; Hydrogen peroxide

\section{Introduction}

There are several chemical ways of generating superoxide anion radical $\left(\mathrm{O}_{2}{ }^{-}\right)$; in the biochemical and medical research fields an enzymatic method using xanthine oxidase is widely used (Figure 1).

\section{Protocol}

Reagents used are Hypoxanthine solution $(1 \mathrm{mM})$ and xanthine oxidase, Fenton reaction.

\section{Procedure}

1. Take hypoxanthine solution $(1 \mathrm{mM})$. For cell culture, use phosphate-buffered saline or foetal calf serum-free medium instead of usual culture medium.

2. Add xanthine oxidase (0.01-100 munits $/ \mathrm{mL}$ ).

3. Incubate for an appropriate time determined experimentally.

4. For cell culture, remove the hypoxanthine solution by aspiration and add the culture medium. The cells are harvested when ready.

\section{Comments}

If xanthine oxidase is used $\mathrm{H}_{2} \mathrm{O}_{2}$ and $\mathrm{O}_{2}^{-}$will be produced. If transition metal ions or their redox active complexes are also present hydroxyl radical will be produced (Fenton reaction). To remove $\mathrm{H}_{2} \mathrm{O}_{2}$ add catalase to the reaction.
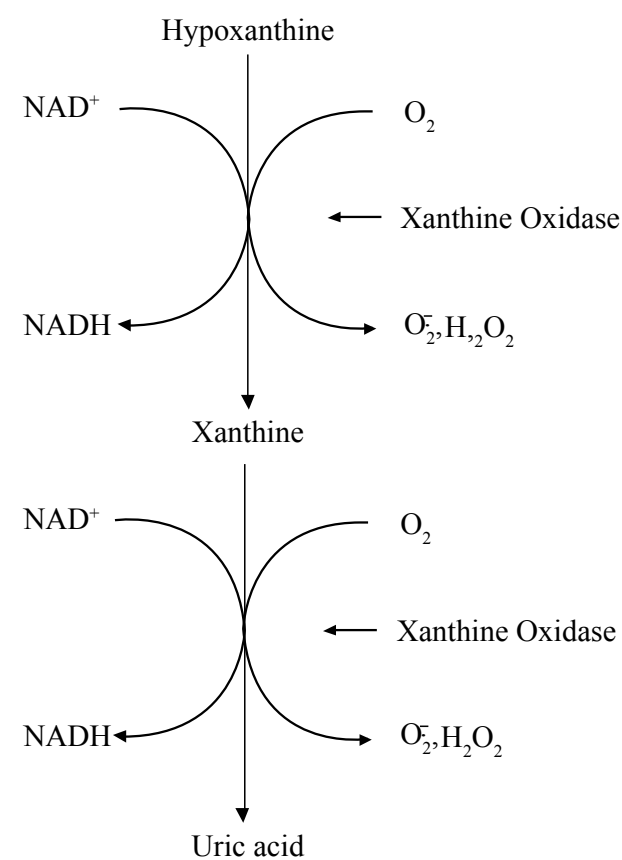

Figure 1: Generation of superoxide. $\left(\mathrm{O}_{2}^{-}\right)$and hydrogen peroxide $\left(\mathrm{H}_{2} \mathrm{O}_{2}\right)$ from hypoxanthine and xanthine oxidase.
*Corresponding author: Hideharu Shintani, Chuo University, School of Science, 1-13-27, Kasuga Bunkyo 112-0003 Tokyo, Japan, Tel: +81425922336; E-mail: shintani@mail.hinocatv.ne.jp

Received May 21, 2013; Accepted June 12, 2013; Published June 15, 2013

Citation: Shintani H (2013) Superoxide Generating System. Pharm Anal Acta S1: 002. doi:10.4172/2153-2435.S1-002

Copyright: (c) 2013 Shintani H. This is an open-access article distributed under the terms of the Creative Commons Attribution License, which permits unrestricted use, distribution, and reproduction in any medium, provided the original author and source are credited. 